IRA-International Journal of Management \&

QUARTERLY

Social Sciences

ISSN 2455-2267; Vol.16, Issue 03 (July-Sep. 2020)

Pg. no. 105-112.

Institute of Research Advances

http://research-advances.org/index.php/RAJMSS

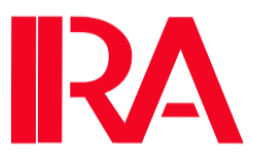

\title{
Influence of Supply Risk Assessment of Third Party Logistics Providers on Performance of Humanitarian Supply Chains: A Case of International Red Cross, Somalia
}

\author{
Aden Iftin Janjane ${ }^{1}$, Jackson Ndolo Muthini ${ }^{2 \#}$ \\ ${ }^{1}$ School of Business and Economics, Mount Kenya University, Kenya. \\ ${ }^{2}$ School of Business and Human Resource Development, Rongo University, Kenya.
}

\# corresponding author

Type of Work: Peer Reviewed.

DOl: http://dx.doi.org/10.21013/jmss.v16.n3.p5

\section{How to cite this paper:}

Janjane, A.I., Muthini, J.N. (2020). Influence of Supply Risk Assessment of Third Party Logistics Providers on Performance of Humanitarian Supply Chains: A Case of International Red Cross, Somalia. IRA-International Journal of Management \& Social Sciences (ISSN 2455-2267), 16(3), 105112. doi:http://dx.doi.org/10.21013/jmss.v16.n3.p5

(C) Institute of Research Advances.

\section{(cc) BY-No}

This work is licensed under a Creative Commons Attribution-NonCommercial 4.0 International License subject to a proper citation to the publication source of the work.

Disclaimer: The scholarly papers as reviewed and published by the Institute of Research Advances (IRA) are the views and opinions of their respective authors and are not the views or opinions of the IRA. The IRA disclaims of any harm or loss caused due to the published content to any party.

Institute of Research Advances is an institutional publisher member of Publishers International Linking Association Inc. (PILA-CrossRef), USA. The institute is an institutional signatory to the Budapest Open Access Initiative, Hungary advocating the open-access of scientific and scholarly knowledge. The Institute is a registered content provider under Open Access Initiative Protocol for Metadata Harvesting (OAI-PMH).

The journal is indexed \& included in WorldCat Discovery Service (USA), CrossRef Metadata Search (USA), WorldCat (USA), OCLC (USA), Open J-Gate (India), EZB (Germany) Scilit (Switzerland), Airiti (China), Bielefeld Academic Search Engine (BASE) of Bielefeld University, Germany, PKP Index of Simon Fraser University, Canada. 


\begin{abstract}
The logistics service industry has evolved quickly to deliver a variety of services including frequently outsourced warehousing, logistics, and freight forwarding, as well as value-added services which include; order management and fulfillment as well as consultancy in the supply chain. The current study sought to establish the influence of supply risk assessment on the performance of humanitarian supply chains in Somalia with a keen focus on the International Red Cross. The study used a descriptive research design. 102 ICR employees operating in Somalia were the target population. The research adopted a technique of census while using a questionnaire to gather primary data. To guarantee validity and reliability, the questionnaire was pre-tested. Using descriptive and inferential statistics data was analyzed and displayed in tables. Key findings of the study included IRC had developed better dispute resolution mechanisms arising from their strategic partnership with their 3PL providers, the organization had enhanced its procurement processes due to its effective assessment of 3PL providers' capacities resulting in minimal supply risk exposure. From correlation analysis, it was established that there existed a strong and positive correlation between supply risk assessment of 3PL Providers and the performance of the ICR supply chain ( $r=$ $0.708 * *, p=.000)$. The study concluded that for enhanced performance of the supply chain $3 P L$ providers should deliver requisitions on time and at desired locations as per orders. It is expected the study findings will find use among logistic practitioners and researchers.
\end{abstract}

Keywords: Third-party logistics, humanitarian supply chain, Performance, risk assessment

\title{
1.0 Introduction
}

Outsourcing logistics to logistics suppliers of third parties (3PL) has been a source of competitive advantage for most businesses (Lucie \& Hudziak, 2012). Most 3PLs have lately shifted from a single feature to integrated delivery of logistics with two or more concurrent tasks (Langley \& Capgemini, 2014). Outsourcing non-core operations to third-party logistics suppliers seek to ensure efficient and effective efficiency of supply chain management of businesses by monitoring the cost of logistics, risk, delivery lead times, and maintaining quality to obtain the required level of service to fulfill their clients. In developed countries, organizations have increasingly turned to third-party logistics providers (3PL) including the USA (Hofer, Knemeyer \& Murphy, 2015) as well as in Europe (Ekeskar \& Rudberg, 2016).

Similarly, in developing countries such as Uganda, studies by Muhindo, Zhou, and Mzuza (2014), indicated that the use of 3PLs had resulted to lower overheads and the fastest possible service. Studies have shown that logistics outsourcing reduces costs from $44 \%$ to $36 \%$ (Wambua, 2017). Thus, it is evident that 3PLs play a crucial role in lowering expenses, productivity, revenues and enhancing the service quality of their clients and thus becoming an important component of supply chain management and effective logistics outsourcing can bring substantial advantages from third parties to both sectors and logistics suppliers (Wambua, 2017; Vishal et al., 2013 \& Ngonela et al., 2014). However, the management of the complex network of supply chain parties which forces firms to use 3PLs further possesses a challenge to the organizations in monitoring and measuring the performance to ensure efficient and effective supply chain performance. While there have been numerous studies that have attempted to address 3PLs and their effect on performance, very few have focused on supply chain performance from a risk assessment perspective. The present study therefore, seeks to establish the influence of supply risk assessment of 3PL providers on the performance of humanitarian supply chains.

Organizations have a high chance to minimize costs while maximizing their income from the use of logistics from third parties. Furthermore, in meeting consumer needs, 3PLs have the potential to improve customer performance. Katana and Gichure (2017) who studied the influence of 3PL providers on supply chain performance in Kenya found that 3PL services improved supplier's performance. The objective populace was 278 staff at East African Breweries Ltd and the information was gathered utilizing a survey. Respondents were inquired as to whether cargo sending influenced flexibly chain execution in East Africa bottling works with 87\% showed yes while $9 \%$ demonstrated no and 5\% didn't know. Respondents were inquired as to whether transportation administrations influenced flexibly chain execution in East Africa bottling works and 91\% demonstrated yes while 9\% showed no. Their investigation anyway was a contextual analysis on one assembling firm and in this manner, the discoveries may not be summed up across various associations.

Njambi and Katuse's (2013) comparative research on how third-party logistics can deliver distribution effectiveness and its contribution to organizations' competitive benefit discovered that 3PLs can be regarded as strategic players in supply chain management as opposed to a specified organization's mere providers. The study however used mail questionnaires which may not be as reliable in the Kenyan context. Furthermore, comparative studies may not yield findings useful for generalizations. Carroll and Neu (2009) examined the philanthropic coordination and flexibly chain errands composing, proposed an alternative speculative building 
uprising up out of that appraisal, and enlivened further conversation and examination around subjects introduced in the key evaluation of military, non-military and composite emergency help coordination, the relationship of compassionate and business gracefully chains and the coordination of philanthropic exercises. As referenced, the investigation was speculative and excluded a variety of data from philanthropic affiliations.

Mbohwa (2010) talked enumerated the difficulties, troubles, and issues looked by humanitarian associations in running logistics frameworks in Southern Africa, with a focal point of certain frameworks in Zimbabwe. Smaller than usual contextual analyses of the tasks of the World Health Organization (WHO), the International Red Cross Society and the Zimbabwe Red Cross Society, the World Food Program, UNICEF, and the Zimbabwean Civil Protection Organization were discussed. The examination ordered the difficulties studied included; absence of prepared logistics staff, absence of access to particular humanitarian logistics courses and research data, the trouble in utilizing and adjusting existing logistics frameworks in taking care of humanitarian logistics, and the absence of cooperative endeavors that address the region explicitly. The investigation concentrated uniquely on Zimbabwe and neighboring nations.

Associations may understand as high as 80 percent yearly turnover in field logistics staff (Thomas, 2003) further exacerbating workforce issues. This outcome in a steady convergence of undeveloped staff, unpracticed in the points of interest of logistics inside the association and alleviation overall. Similarly, Njagi (2017) observed that the vertical integration of provider tasks and distribution operations to maximize production and logistical control has been useful in the past for big manufacturing organizations. However, their research looked at the logistics outsourcing elements. Furthermore, their study used cluster sampling which may not be appropriate in studying Humanitarian organizations. As the debate on benefits as well as the risks posed by outsourcing logistics ranges among researchers and practitioners its critical to assess the role supply risk assessment plays in selecting the right 3PL provider and its effect on the performance of the organization's supply chain.

\subsection{Literature Review}

Successful logistics outsourcing can bring substantial advantages. The objectives and concerns relating to the outsourcing of 3PL logistics are cost reduction, improved delivery times, quality service delivery, risk assessment, concentration on core competencies, increased flexibility, and concerns are loss of control, dependence on service. As indicated by Katana and Gichure (2017) in their study on the influence of third-party logistics providers on supply chain performance in Kenya, 3PL services had improved supplier's performance. The objective populace was 278 staff at East African Breweries Limited and the information was gathered utilizing a poll. Respondents were inquired as to whether cargo sending influenced flexibly chain execution in East Africa bottling works with $87 \%$ demonstrated yes while $9 \%$ showed no and 5\% didn't know. Respondents were asked as to whether transportation administrations influenced flexibly chain execution in East Africa distilleries and $91 \%$ demonstrated yes while $9 \%$ showed no. The investigation suggested that the requirements of the organization and the non-center business be deliberately broke down to settle on educated choices about the correct coordination's administrations for redistributing. They noticed that structuring proper coordination's the board rehearses in accordance with authoritative exercises was of fundamental significance, so improving vehicle productivity could change the general flawlessness.

According to Lysons and Farrington (2006), the risk is an activity or undertaking that may have an adverse impact on the achievement of an objective such as outsourcing objective. Risk assessment is the process of identifying, analyzing, and evaluating hazards or uncertainties and determination of the likelihood of occurrence of each risk factor (Tummala \& Schoenherr, 2011). Therefore, outsourcing a 3PL provider may introduce or reduce risk to the client business. Risk assessment is therefore concerned with identifying and evaluating all potential risks in outsourcing 3PL providers. The assessment process allows the 3PL providers to develop a risk matrix based on the probability of occurrence or vulnerability and device methods to mitigate or safeguard the impact.

According to Ellramet et al., (2008), outsourcing may adversely affect the firm's performance by increasing its operating costs which include staff training to monitor and communicate the performance of 3PL. Besides, when companies outsource some services from experts they benefit because service providers are better placed in making accurate estimates and providing better alternatives. The outsourced 3PL providers undertake to invest in equipment, networks, and resources to provide the service thereby sharing risks with its clients. According to Aron et al., (2005), outsourcing to 3PLs plays a crucial role in spreading logistics risk and a company needs to select the right 3PL providers from the beginning. The 3PLs providers should have the necessary processes, quality, technology, employees, and equipment in order to qualify for appointment (Kumar \& Eichhoff, 2005). Their study suggests that selection of 3PLs providers must be made using a cross-functional team to ensure that 
all aspects are taken into consideration. They noted that the selection of 3PL providers may be based on various factors including; previous performance, capacity, cost, lead-time, risk assessment, quality, and among others. Through risk assessment, a company is able to reveal the risks associated with logistics service provision and put in place appropriate mitigating measures. Therefore, the outcome of risk assessment forms the basis of appointing or failing to appoint a $3 \mathrm{PL}$ provider.

Supply chain performance perceives that the serious quality of a firm isn't just dictated by its items yet in addition by the tasks and exercises that place the items into clients' hands and offer supporting types of assistance. Productive and successful SCM upgrades firm performance and includes an incentive by expanding resource usage to increase the serious market advantage. The responsiveness and proficiency of an organization's supply chain emerging from its plan and the board are indispensable to the association's capacity to effectively contend in the worldwide commercial center. The performance of the supply chain is the capacity of an organization to procure products or services as cost-effectively as possible while ensuring that its goods, services, and help are of high quality (Scheraga, 2004). It is often accomplished by streamlining an organization's key procedures to react more cost-effectively to the ever-changing market forces. An organization requires minimizing redundancy and waste in order to attain effectiveness while leveraging the resources that contribute most to its achievement and make the best use of its workers, technology, and company procedures. The lower inner expenses arising from the supply chain's effectiveness allow an organization to attain greater profit margins or more success in an extremely competitive brand. Hence the researchers hypothesized that;

\section{$\boldsymbol{H}_{0}:$ Risk assessment of $3 P L$ s has no significant influence on the performance of humanitarian supply chains}

\subsection{Research Methodology}

A descriptive survey design was adopted in this study. The design connects the study's questions or goals to the collected data. The method is preferred as it allows data to be collected in natural settings from the respondents (Mugenda \& Mugenda, 2010). The study targeted 102 ICR staff in Somalia, including 21 contracting staff, 21 human resource staff, 24 finance staff, and 36 support staff. Since the study population was relatively small the study adopted a census technique that studied all the 102 ICR employees in Somalia.

Before the administration of the questionnaires, an introductory and ethical clearance certificate letter was sought from Mount Kenya University. Primary data was obtained from the 102 ICR staff in Somalia through the drop and pick method. Filled questionnaires were picked after two weeks for processing. After data collection, the questionnaires were sorted out to identify and quarantine those not properly filled. Data was summarized into the various categories as per research questions.

The study model took the form;

$$
\mathrm{Y}=\beta_{0}+\beta_{1} X_{1}+\dot{\varepsilon}
$$

Where: $Y=$ Supply Chain Performance, $\mathrm{X}_{1}=$ Risk Assessment, $\beta_{0}$ and $\beta_{1}=$ Beta Coefficients while $\varepsilon=$ Error Term.

Levels of significance were determined for each $\beta$ value (slope). The common overall fit measure used in the study was the coefficient of determination $\left(\mathrm{R}^{2}\right)$, based on the sum of ANOVA table squares (Orodho, 2005). Based on other related information, the determination coefficient $\mathrm{R}^{2}$ was used in the model to predict future outcomes. The main test of the importance of the research was to find out whether the independent variable (Supply Risk Assessment) determined the dependent variable (supply chain performance).

\subsection{Results and Discussions}

Out of 102 questionnaires that were given, 90 of them were filled and returned of while 10 were erroneously filled and hence not utilized in the final analysis constituting a 78.4\% response rate. The study found that a larger part of the respondents $(53.75 \%)$ had a degree-level qualification. Further, over $78 \%$ of the respondents had either a bachelor's or master's degree. This trend was attributed to the professionalization of the procurement sector which has compelled most procurement staff to seek higher educational qualifications as per the compliance stipulates. Most of the respondents $(47.5 \%)$ had over 11 years of working experience. Cumulatively, more than $77.5 \%$ had more than 8 years of experience while only $6.25 \%$ had less than 3 years of working experience. The study attributed this trend to the fact that the public and private sectors in the past decade have stagnated in creating new job opportunities for new job entrants. 
Table 1: Risk Assessment and Supply Chain Performance

\begin{tabular}{|c|c|c|c|c|c|c|c|}
\hline & SD & D & $\mathbf{N}$ & $\mathbf{A}$ & $\mathbf{S A}$ & Mean & Std Dev \\
\hline $\begin{array}{l}\text { Our firm's procurement process is enhanced } \\
\text { through effective assessment of our 3PL } \\
\text { providers }\end{array}$ & $\begin{array}{c}3 \\
(3.8 \%)\end{array}$ & $\begin{array}{c}5 \\
(6.3 \%)\end{array}$ & $\begin{array}{c}9 \\
(11.3 \% \\
)^{9}\end{array}$ & $\begin{array}{c}35 \\
(43.8 \%)\end{array}$ & $28(35.0 \%)$ & 4.00 & 1.031 \\
\hline $\begin{array}{l}\text { We asses our } 3 \mathrm{PL} \text { capacity before engaging } \\
\text { them }\end{array}$ & $\begin{array}{c}1 \\
(1.3 \%)\end{array}$ & $\begin{array}{c}7 \\
(8.8 \%)\end{array}$ & $\begin{array}{c}10 \\
(12.5 \% \\
)^{2}\end{array}$ & $\begin{array}{c}45 \\
(56.3 \%)\end{array}$ & $17(21.3 \%)$ & 3.88 & .891 \\
\hline $\begin{array}{l}\text { Our firm has recorded reduced damages and } \\
\text { breakages of our deliveries }\end{array}$ & $\begin{array}{c}3 \\
(3.8 \%)\end{array}$ & $\begin{array}{c}2 \\
(2.5 \%)\end{array}$ & $\begin{array}{c}21 \\
(26.3 \% \\
)\end{array}$ & $\begin{array}{c}31 \\
(38.8 \%)\end{array}$ & $23(28.8 \%)$ & 3.86 & .990 \\
\hline $\begin{array}{l}\text { Our partnerships with our 3PL providers have } \\
\text { made us reduce service interruptions }\end{array}$ & $(1.3 \%)$ & $\begin{array}{c}4 \\
(5 \%)\end{array}$ & $\begin{array}{c}9 \\
(11.3 \% \\
)^{9}\end{array}$ & $36(45 \%)$ & $30(37.5 \%)$ & 4.12 & .891 \\
\hline $\begin{array}{l}\text { The firm has reduced customer delays due to } \\
\text { the synergies provided by our } 3 \text { PL providers }\end{array}$ & $\begin{array}{c}2 \\
(2.5 \%)\end{array}$ & $\begin{array}{c}3 \\
(3.8 \%)\end{array}$ & $\begin{array}{c}16 \\
(20.0 \% \\
)\end{array}$ & $\begin{array}{c}36 \\
(45.0 \%)\end{array}$ & $23(28.8 \%)$ & 3.94 & .932 \\
\hline $\begin{array}{l}\text { Our firm has recorded minimum losses due to } \\
\text { enhanced 3PL partnership }\end{array}$ & $\begin{array}{c}2 \\
(2.5 \%)\end{array}$ & $\begin{array}{c}3 \\
(3.8 \%)\end{array}$ & $\begin{array}{c}8 \\
(10.0 \% \\
)\end{array}$ & $\begin{array}{c}42 \\
(52.5 \%)\end{array}$ & $25(31.3 \%)$ & 4.06 & .891 \\
\hline Valid N (listwise) & 80 & & & & & & \\
\hline
\end{tabular}

Source: Field Data (2020)

From Table 1, the majority of the respondents $78.8 \%$ agreed that their firm had enhanced its procurement processes due to their effective assessment of 3PL providers while $10.1 \%$ disagreed. $77.6 \%$ agreed that the capacity of their 3PL provider was one of the key components assessed before engaging them while $10.1 \%$ disagreed. $67.6 \%$ agreed that their firm had recorded reduced damages and breakages of deliveries while $6.3 \%$ disagreed. $82.5 \%$ agreed that partnerships with 3PL providers had made them reduce service interruptions while only $6.3 \%$ disagreed. $73.8 \%$ agreed that the firm had reduced customer delays due to the synergies provided by 3PL providers while $6.3 \%$ disagreed. Finally, $83.8 \%$ agreed that their firm had recorded minimum losses due to enhanced 3PL partnership while $6.3 \%$ disagreed. From the findings on Table 1, it was established that the majority of the respondents agreed that their firm had enhanced its procurement processes due to their effective assessment of 3PL providers, that the capacity of their 3PL provider was one of the key component assessed before engaging them, that their firm had recorded reduced damages and breakages of deliveries, that partnerships with 3PL providers had made them reduce service interruptions, that their firm had reduced customer delays due to the synergies provided by 3PL providers and that their firm had recorded minimum losses due to enhanced 3PL partnership.

Table 2: Measurement of Supply Chain Performance

\begin{tabular}{|c|c|c|c|c|c|c|c|}
\hline & SD & D & $\mathbf{N}$ & $\mathbf{A}$ & $\mathbf{S A}$ & Mean & $\begin{array}{l}\text { Std } \\
\text { Dev }\end{array}$ \\
\hline $\begin{array}{l}\text { Our firm offers timely deliveries of } \\
\text { requisitions out of its efficient } \\
\text { procurement process }\end{array}$ & $1(1.3 \%)$ & $\begin{array}{l}2 \\
(2.5 \%)\end{array}$ & $\begin{array}{c}6 \\
(7.5 \%)\end{array}$ & $\begin{array}{c}42 \\
(52.5 \%)\end{array}$ & $\begin{array}{c}29 \\
(36.3 \%)\end{array}$ & 4.20 & .786 \\
\hline $\begin{array}{l}\text { There are minimal complaints on the } \\
\text { procurement process due to its efficiency }\end{array}$ & $2(2.5 \%)$ & $2(2.5 \%)$ & $\begin{array}{c}11 \\
(13.8 \%)\end{array}$ & $\begin{array}{c}45 \\
(56.3 \%)\end{array}$ & $\begin{array}{c}20 \\
(25.0 \%)\end{array}$ & 3.99 & .849 \\
\hline $\begin{array}{l}\text { Wastages and damages have been reduced } \\
\text { due to the efficiency of the procurement } \\
\text { process }\end{array}$ & $\begin{array}{l}3 \\
(3.8 \%)\end{array}$ & $\begin{array}{c}4 \\
(5 \%)\end{array}$ & $\begin{array}{c}16 \\
(20.0 \%)\end{array}$ & $\begin{array}{c}36 \\
(45.0 \%)\end{array}$ & $\begin{array}{c}21 \\
(26.3 \%)\end{array}$ & 3.85 & .995 \\
\hline $\begin{array}{l}\text { The efficiency of the procurement process } \\
\text { has led to cost reduction in our firm. }\end{array}$ & $2(2.5 \%)$ & $\begin{array}{c}4 \\
(5.0 \%)\end{array}$ & $\begin{array}{c}15 \\
(18.8 \%)\end{array}$ & $\begin{array}{c}38 \\
(47.5 \%)\end{array}$ & $\begin{array}{c}21 \\
(36.3 \%)\end{array}$ & 3.90 & .936 \\
\hline $\begin{array}{l}\text { Our procurement system achieves value } \\
\text { for money }\end{array}$ & $\begin{array}{c}4 \\
(5.0 \%)\end{array}$ & $2(2.5 \%)$ & $\begin{array}{c}17 \\
(21.3 \%)\end{array}$ & $\begin{array}{c}28 \\
(35.0 \%)\end{array}$ & $\begin{array}{c}29 \\
(36.3 \%)\end{array}$ & 3.95 & 1.066 \\
\hline
\end{tabular}




\begin{tabular}{|c|c|c|c|c|c|c|c|}
\hline $\begin{array}{l}\text { There is adequate level of knowledge of } \\
\text { procurement process and procedure at } \\
\text { work }\end{array}$ & $\begin{array}{c}2 \\
(2.5 \%)\end{array}$ & $6(7.5 \%)$ & $\begin{array}{c}13 \\
(16.3 \%)\end{array}$ & $\begin{array}{c}33 \\
(41.3 \%)\end{array}$ & $\begin{array}{c}26 \\
(32.5 \%)\end{array}$ & 3.94 & 1.011 \\
\hline $\begin{array}{l}\text { Our firm also provides adequate and } \\
\text { continuous training on procurement } \\
\text { operations }\end{array}$ & $\begin{array}{c}2 \\
(2.5 \%)\end{array}$ & $\begin{array}{c}4 \\
(5.0 \%)\end{array}$ & $8(10.0 \%)$ & $\begin{array}{c}33 \\
(41.3 \%)\end{array}$ & $\begin{array}{c}33 \\
(41.3 \%)\end{array}$ & 4.14 & .964 \\
\hline Valid N (listwise) & 80 & & & & & & \\
\hline
\end{tabular}

Source: Field Data (2020)

From the findings, $88.3 \%$ agreed that their firm offered timely deliveries of requisitions out of its efficient procurement process while $3.8 \%$ disagreed. 81.6 agreed that they were minimal complaints on the procurement process due to its efficiency while 5\% disagreed. $71.6 \%$ agreed that wastages and damages had been reduced due to the efficiency of the procurement process while $8.8 \%$ disagreed. $83.8 \%$ agreed that the efficiency of the procurement process had led to cost reduction in their firm while 5\% disagreed. $71.3 \%$ agreed that the procurement system achieves value for money while $7.5 \%$ disagreed. $73.8 \%$ agreed that there was an adequate level of knowledge of procurement process and procedure at work while $10 \%$ disagreed. $82.6 \%$ agreed that their firm provided adequate and continuous training on procurement operations while $7.5 \%$ disagreed. Furthermore, from the findings, the majority of the respondents agreed that their firm offered timely deliveries of requisitions out of its efficient procurement process (4.20), that they were minimal complaints on the procurement process due to its efficiency (3.99), that wastages and damages had been reduced due to the efficiency of the procurement process (3.85), that the efficiency of the procurement process had led to cost reduction in their firm (3.90), that the procurement system achieves value for money (3.95), that there was an adequate level of knowledge of procurement process and procedure at work (3.94) and that they provided adequate and continuous training on procurement operations (4.14).

The respondents' ratings in the statements related to supply risk assessment were cumulated to obtain a composite score for risk assessment. The total scores were then used to compute Pearson's correlation to establish the nature and strength of the correlation between risk assessment and performance of supply chains shown in Table 3.

Table 1: Risk Assessment and Performance of Supply Chain

\begin{tabular}{llcc}
\hline & \multicolumn{1}{c}{ Supply Chain Efficiency } & Risk Assessment \\
\hline \multirow{2}{*}{ Performance of supply chain } & Pearson & 1 & $.708^{* *}$ \\
& Correlation & & .000 \\
& Sig. (2-tailed) & 80 & 80 \\
\hline
\end{tabular}

**. Correlation is significant at the 0.01 level (2-tailed).

Source: Field Data (2020)

From the correlation analysis in Table 3, it was established that there was a very strong and positive correlation between risk assessment and performance of the supply chain $\left(r=0.708^{* *}, p=.000\right)$. Since the correlation was very strong and positive in nature, the study deduced that it implied that very high levels of performance of the supply chain can be associated with risk assessment. Based on these findings, the study concluded that risk assessment has a significant influence on supply chain efficiency. The findings are in agreement with those of Wambua (2017) who found out that risk assessment was a significant predictor in the performance of food and beverage manufacturing companies in Kenya.

The researchers carried out a regression analysis to establish the influence of the independent variable on supply chain efficiency. The model summary is depicted in Table 4.

Table 2: Model Summary

\begin{tabular}{ccccc}
\hline Model & R & R Square & Adjusted R Square & Std. Error of the Estimate \\
\hline 1 & $.767^{\text {a }}$ & .589 & .567 & .37420 \\
\hline
\end{tabular}

a. Predictors: (Constant), lead time, service quality, risk assessment \& costs

Source: Field Data (2020) 
The $\mathrm{R}^{2}$ estimation of 0.589 infers that $58.9 \%$ of the varieties in supply chain performance can be clarified by the varieties in free factors. This implies that different elements not concentrated in this examination contribute $41.1 \%$ of supply chain productivity.

The study conducted a multiple regression analysis and the findings of the multiple regression model is shown in Table 5.

Table 5: Regression Coefficients

\begin{tabular}{lccccc}
\hline & $\begin{array}{c}\text { Unstandardized } \\
\text { Coefficients }\end{array}$ & $\begin{array}{c}\text { Standardized } \\
\text { Coefficients }\end{array}$ & & \\
& & & & \\
& BE & B & $\mathbf{t}$ & $\mathbf{p}$ & .000 \\
Constant & 1.286 & .298 & & 4.316 & .000 \\
Risk Assessment & .383 & .092 & .443 & 4.172 & \\
\hline
\end{tabular}

a. Dependent Variable: Supply Chain Performance

Source: Field Data (2020)

From the model, holding the independent variables constant, the performance of the supply chain would increase by 1.286 . It was observed that a unit increment in hazard appraisal would cause an expansion in supply chain performance by a factor of 0.383 . The un-normalized beta coefficients in Table 5 were then used to acquire the general relationship of the free factors and the needy variable and model was detailed as: $\mathrm{Y}=1.286-0.029$ Supply Risk Assessment +0.443;

From the multiple regression analysis, the ANOVA test results are presented in Table 16.

Table 3: ANOVA of Independent Variable and Dependent Variable

\begin{tabular}{llllll}
\hline & Sum of Squares & df & Mean Square & F & Sig. \\
\hline Regression & 15.026 & 4 & 3.757 & 26.828 & $.000^{b}$ \\
Residual & 10.502 & 75 & .140 & & \\
Total & 25.528 & 79 & & & \\
\hline
\end{tabular}

a. Dependent Variable: Supply Chain Performance

b. Predictors: (Constant), Supply Risk Assessment

Source: Field Data (2020)

From the ANOVA results, since the p-value (.000) was obtained, it was concluded that at a $5 \%$ significance level, the effect of the independent variable has a statistically significant influence on the performance of the supply chain in humanitarian organizations. The hypothesis was conveyed at a $5 \%$ critical level utilizing pvalues in Table 6 . The study attempted to test the legitimacy of the principal hypothesis of the study which expressed: $\mathrm{H}_{0}$ : Supply Risk Assessment of 3PLs has no significant influence on the Performance of humanitarian Supply Chain. Since the p-values $(.000<.05)$, the researchers dismiss the null hypothesis and reason that at $5 \%$ criticalness level, risk assessment has a huge effect on the performance of supply chains.

\subsection{Conclusions and Recommendations}

The study established that IRC, Somalia had enhanced its procurement processes due to effective assessment of 3PL providers (4.00), the capacity of their 3PL providers was one of the key component assessed before engaging them (3.88), that they had recorded reduced damages and breakages of deliveries (3.86), that partnerships with 3PL providers had made them reduce service interruptions (4.12), that they had reduced customer delays due to the synergies provided by 3PL providers (3.94) and that they had recorded minimum losses due to enhanced 3PL partnership (4.06). Further, it was established that there was a very strong and positive correlation between supply risk assessment and performance of the supply chain $\left(\mathrm{r}=0.708^{* *}, \mathrm{p}=.000\right)$. Since the correlation was very strong and positive in nature, the study deduced that it implied that very high levels of performance of the supply chain can be associated with effective supply risk assessment. Based on these findings, the study concluded that supply risk assessment has a significant influence on supply Performance. Therefore, humanitarian organocations should embrace strategic supply risk assessment methods and tools so as to enhance their supply chain performance. The study recommends further research on other factors that affect supply chain performance as well as a similar study of other sectors. 


\section{References}

[1]. Aron, R., Clemons, E.K., Reddi, S.P. (2005) Just right outsourcing: Understanding and managing risk. Journal of Management Information Systems 22(2), 37-55.

[2]. Beer, J. (2011). Rethink, reinvent and renew. Efficient Purchasing 12/2011, 18-22.

[3]. Bolumole, Y. (2001), "The Supply Chain Role of Third-Party Logistics Providers",. International Journal of Logistics Management, Vol. 12, No. 2, pp. 87-102.

[4]. Drake, M. (2012). Global Supply Chain Management. London: Business Expert Press.

[5]. Ekeskar, A. and M. Rudberg, 2016. Third-party logistics in construction: The case of a large hospital project. Constr. Manage. Econ., 34: 174-191.

[6]. Gronroos, C. (2004). The relationship marketing process: communication, interaction, dialogue, value. Journal of Business and Industrial Marketing, 19(2), 99-113.

[7]. Karrapan, C., Sishange, M., Swanepoel, E., \& Kilbourn, P. J. (2017). Benchmarking criteria for evaluating thirdparty logistics providers in South Africa. Journal of Transport and Supply Chain Management, 11(1), 1-10.

[8]. Kirui, E.K., \& Wanyoike, D. (2015). Factors influencing procurement efficiency at the national hospital insurance fund in Kenya. IMPACT: InternationalJournal of Research in Business Management (IMPACT:IJRBM) ISSN(E): 2321-886X; ISSN(P): 2347-4572 Vol.3, Issue 11, Nov 2015, 29-42.

[9]. Kyusya, J. M. (2015). Effect of logistics outsourcing on the operational performance of shipping industry in Kenya. University of Nairobi.

[10]. Leuschner, R., Carter, C. R., Goldsby, T. J., \& Rogers, Z. S. (2014). Third-party logistics: a meta-analytic review and investigation of its impact on performance. Journal of Supply Chain Management, 50(1), 21-43.

[11]. Melkam, A. (2016). The Effects of Outsourcing Logistics Activities of Ethiopian Airlines on ts Logistics Performance (Doctoral Exposition, AAU Repository).

[12]. Njagi, W. A. (2017). Effect of Outsourcing Logistics to Third Party Providers on Performance of Manufacturing Firms in Kenya. Unpublished Master Thesis, KCA University, Kenya.

[13]. Saunders, M., Lewis, P., \& Thornhill, A. (2003). Research methods for business students. Essex: Prentice Hall: Financial Times.

[14]. Wambua, J. M., (2017). Influence of Outsourcing Third-Party Logistics on the Performance of Food and Beverages Manufacturing Companies in Kenya. JKUAT Repository. 